\title{
The importance for a start-up to trust in Open Innovation: A systematic literature review
}

\author{
Katia Mastrostefano ${ }^{1}$ • Gustavo Morales-Alonso, ${ }^{2 *} \bullet$ Marco Greco $^{1} \bullet$ \\ Michele Grimaldi $^{1}$ • Jose Antonio Blanco-Serrano ${ }^{2}$ \\ ${ }^{1}$ Università degli Studi di Cassino e del Lazio Meridionale, Cassino, Italy \\ ${ }^{2}$ Universidad Politécnica de Madrid, Madrid, Spain
}

Received: 23 October 2019

Revised: 28 February 2020 Accepted: 30 April 2020

\begin{abstract}
It has long been known that new firms are fundamental for economic growth. Starting new companies is one of the best ways to fight unemployment and to generate well-being. Therefore, attention is paid by the scientific community to start-ups, with particular empha-sis at how they generate, acquire and manage innovation. Initially, start-ups need to identify the resources necessary for innovation and later they will decide whether to develop them internally or acquire them externally. Being open to external sources is a crucial point for the success of new ventures; indeed, adopting Open Innovation processes allows start-ups to overcome their initial shortcomings. The goal of this research is to understand the literature status related to Open Innovation adoption by start-ups.
\end{abstract}

Keywords: entrepreneur; successful collaboration; knowledge acquisition; new technologybased firms; new ventures

JEL Classification Codes: O31, O32, O34

\section{Introduction}

Entrepreneurship has been thoroughly mentioned as a crucial parameter for economic growth, employment and innovation (Carree and Thurik 2010; Wennekers and Thurik 1999; MoralesAlonso et al. 2016). Therefore, the scientific community is paying particular attention to startups (Kohler 2016, Morales-Alonso et al. 2020).

According to Steve Blank (2012) "A start-up is a temporary organization in search of a scalable, repeatable, profitable business model. At the outset, the start-up business model is a canvas covered with ideas and guesses, but it has no customers and minimal customer knowledge".

\footnotetext{
*Corresponding author. E-mail: gustavo.morales@upm.es.

Citation: Mastrostefano, K., Morales-Alonso, G., Greco, M., Grimaldi, M., and Blanco-Serrano, J. A. (2020) The importance for a start-up to trust in Open Innovation: A systematic literature review, Economics and Business Letters, 9(4), 289-297.
}

DOI: $10.17811 /$ ebl.9.4.2020.289-297 
Notably, a study from Harvard Business School found that three out of four start-ups fail (Blank 2013). This low survivability rate can be attributed, totally or partially, to the many challenges faced by the entrepreneurs, such as the newness and smallness of the firm, market entry barriers, limited resources, lack of market knowledge and the financial means (Eftekhari and Bogers 2015; Gruber and Henkel 2006; Morales-Alonso et al. 2019).

These challenges could be faced with the use of Open Innovation (OI) techniques. Chesbrough (2003) has defined OI as "a paradigm that assumes that firms can and should use external ideas as well as internal ideas, and internal and external paths to market, as the firms look to advance their technology". According to Janssen et al. (2014), companies should collaborate with their stakeholders to accelerate innovation and to favour technology acquisition and development, while Hidalgo et al. (2020) highlight the importance of accesing technology to reduce the digital divide.

There are two main processes that companies can use in their open innovation model: inbound open innovation, which refers to the internal use of external knowledge coming from partners, customers, suppliers or universities; and outbound open innovation, which consists in taking advantage of bringing ideas or skills to the market through solutions that are outside the company (Chesbrough et al. 2006). Moreover, Gassmann and Enkel (2004) also introduced a third type of process, defined as coupled innovation. Companies that adopt this model aim to integrate the inbound process with outbound through collaborations, alliances or joint ventures.

Bogers (2011) found that adopting open innovation processes allows start-ups to overcome their initial shortcomings. Spender et al. (2017) highlighted that a strong correlation between start-ups and OI exists, although they found a paucity of studies on the topic. Most of the existing research focused on the use of OI practices in big companies, with a few studies devoted to new ventures (Alberti and Pizzurno 2017; Usman and Vanhaverbeke 2017). The approaches to OI that can be adopted by start-ups are not the same as in large companies, due to the different strategic purposes they have (Usman and Vanhaverbeke 2017).

This study aims at shedding light on the existing literature related to start-ups and OI. The most relevant articles on the topic were identified and elaborated to present the most promising streams of research and highlight proposals for future research endeavours.

\section{Methods}

Data collection was performed through a systematic review of the literature. This is a qualitative methodology that nevertheless allows minimizing researcher bias regarding the inclusion or exclusion of previous publications when properly conducted. The trimming of the selected sample, that is, the reduction from 136 to 34 papers was conducted in parallel by the two first authors of the paper. This helps to double-check inclusion and exclusion criteria and reduce researcher bias. It is valuable, as it presents the transparency of the review. To carry out the systematic literature review, the steps defined by Johnsen et al. (2017) were followed.

First, the review is planned, then conducted, and finally the report of the findings is presented. This section summarizes how the review was planned and conducted. A four-step process was followed, as shown in Figure 1.

For this research, the "open innovation", "start-up" and "start up" keywords were identified. Subsequently, the search strings were built, following the Boolean logic. Two strings were crafted, namely (Open innovation) AND (start-up), and (Open innovation) AND (start up). Then, databases needed to be selected, which resulted in searches conducted in Scopus, Google Scholar and Science Direct. 
Figure 1. Flow-chart of the research process.

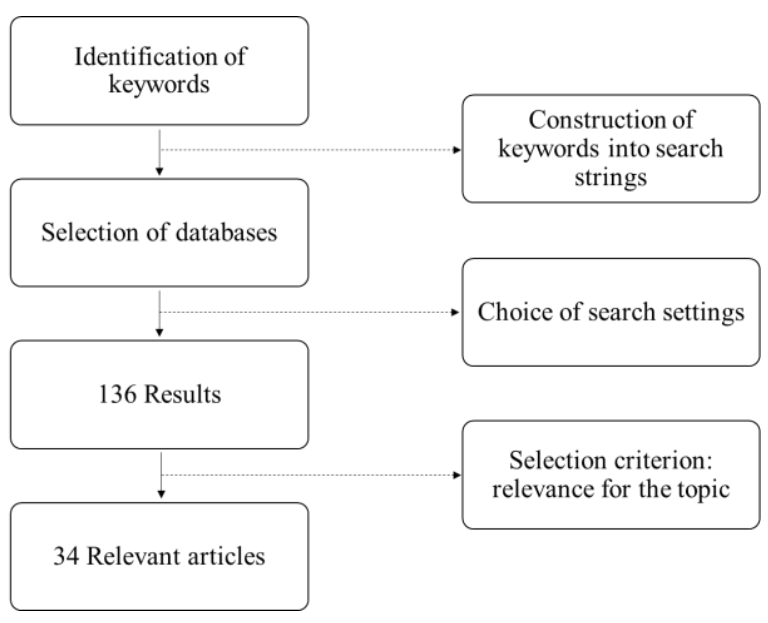

In the following, a filtering decision was taken: to narrow results down to peer-reviewed papers, in the aim of assuring scientific relevance. From an original amount of 136 papers, research was narrowed down to 34 relevant articles. Information was collected for each paper regarding the main topics dealt with; the results obtained from the study and suggestions for future researches. These results were summarized on a matrix, which allowed classifying the articles, to identify three fundamental aspects: the main topics, the side from which the study was made, subjects studied, and on which side it would be appropriate to extend the studies.

\section{Data}

From the final selection of 34 articles, the following information was collected: the country under study, the name of the journal, the innovation actors object of the study and theme analysed, the results obtained and the proposals for future researches.

Regarding the country under study, it is noteworthy that the topic "Start-up and OI" has attracted attention from 13 different countries (see Figure 2). Italy is the country on the front line; in fact, the articles with this origin are over $20 \%$ of the sample. Important presences are those of other countries such as the USA, Germany and UK.

Concerning the distributions of the journals, the most present ones are European Journal of Innovation Management, California Management Review and Research-Technology Management. Other 18 journals were also identified that deal with various topics such as innovation and technology management, entrepreneurship and business strategy.

By observing the years of publication of the articles (see Figure 3), it is possible to notice, first, the novelty of the topic (no articles were found prior to 2006), and second, the significant growth of interest in this topic.

Figure 2. Overview of the research articles by country.

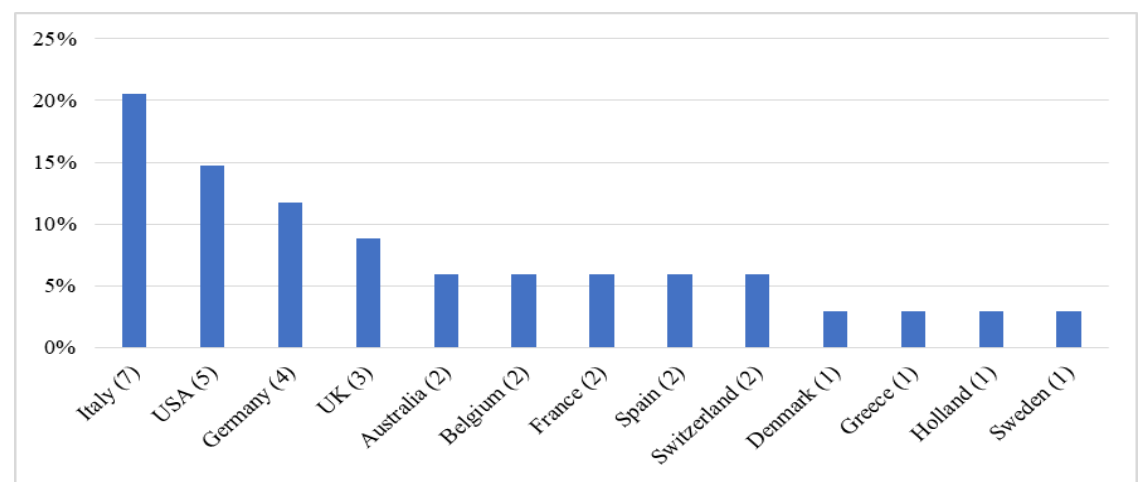


Figure 3. Distribution of research articles by the year of publication. The dotted line represents the polynomial tendency curve of the 2 nd order.

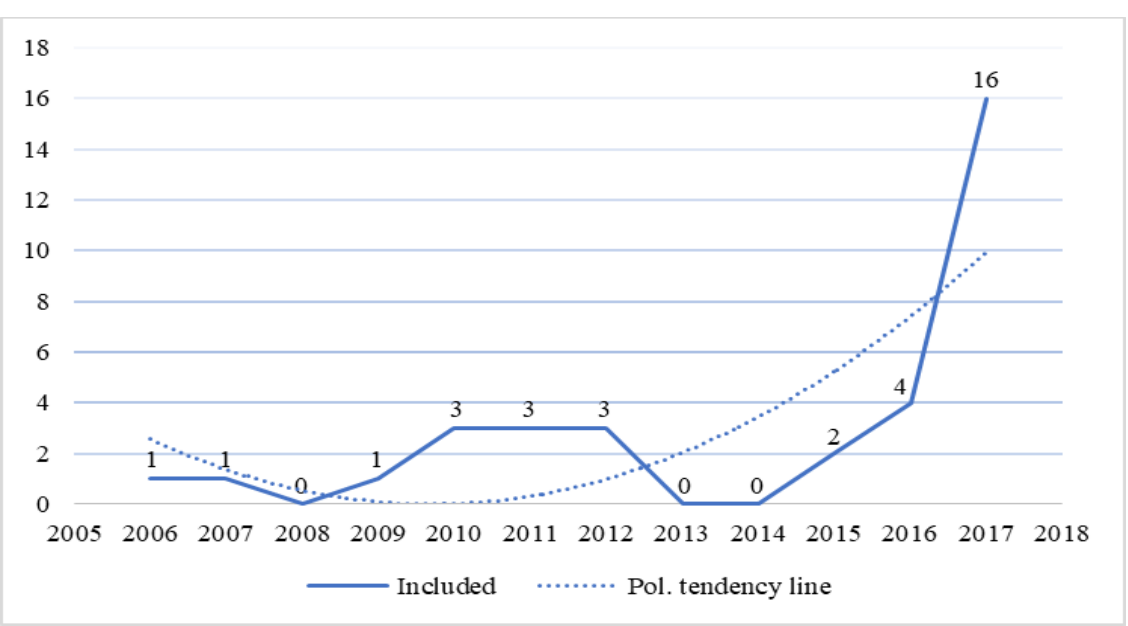

With respect to the scientific approach, 18 rely on a qualitative approach, while 8 use a quantitative approach and the remaining 8 use a combination of both methods.

\section{Results}

When the actors in which the articles focus are sought after, it can be concluded that 19 of them explicitly deal with Start-ups, while 23 focus on Other actors.

Out of these other actors, Universities, large companies and venture capital (VC) firms are highlighted. It is worth noting the transdisciplinarity of OI research, as some papers focus on with financing (Livieratos and Lepeniotis 2017), intellectual property (Belingheri and Leone 2017), transaction costs (Hsieh et al. 2016), and alliances (Jackson and Richter 2017).

Among the specific topics dealt with, the following have been identified (i) entrepreneurship, which is dealt with in 11 references, (ii) firm performance (14 papers), (iii) knowledge (10) and (iv) ties (cited in 25 papers).

Lastly, the directions of future research recommended in each paper have also been sought after. A summary of the results is shown in Table 1.

\section{Concluding remarks}

The systematic literature review has provided a classification framework consisting of four different topics: (i) entrepreneurship, (ii) firm performance, (iii) knowledge and (iv) ties.

In relation with the papers analyzing the factors that influence the performance of a start-up, Battistella et al. (2017) showed that being placed in an open environment allows start-ups to overcome their initial limits such as the resources, the newness and the size. The same line follows the study by Eftekhari and Bogers (2015) who, through interviews, examined how OI influences the creation and survival of start-ups. They identify some factors that affect the survival of start-ups and conclude that OI helps start-ups to fill some initial gaps that characterize them. In their article, Ghezzi et al. (2016) emphasized how start-ups innovated through social media, and argued that it would be necessary to validate the hypothesis that "start-ups' ability to collect funds from institutional investors, venture incubators, business angels, etc. anticipates their ability to generate revenues and profits". Michelino et al. (2017) examined the ties involving the start-ups and suggest the need of defining the business characteristics that influence the choice of partners and the factors that influence the performance of collaborations. 
Table 1. Matrix classification of the articles.

\begin{tabular}{|c|c|c|c|c|c|c|c|c|c|c|}
\hline \multirow[b]{2}{*}{ Article } & \multicolumn{3}{|c|}{ Subjects studied } & \multicolumn{4}{|c|}{ Main themes } & \multicolumn{3}{|c|}{ Need to expand studies } \\
\hline & $\begin{array}{l}\text { Start- } \\
\text { ups }\end{array}$ & $\begin{array}{l}\text { Other } \\
\text { actors }\end{array}$ & $\begin{array}{c}\text { Both } \\
\text { subjects }\end{array}$ & $\begin{array}{l}\text { Entre- } \\
\text { preneur }\end{array}$ & $\begin{array}{l}\text { Firm per- } \\
\text { formance }\end{array}$ & $\begin{array}{l}\text { Know- } \\
\text { ledge }\end{array}$ & Ties & $\begin{array}{l}\text { Start- } \\
\text { ups }\end{array}$ & $\begin{array}{l}\text { Other ac- } \\
\text { tors }\end{array}$ & $\begin{array}{l}\text { Both sub- } \\
\text { jects }\end{array}$ \\
\hline Alberti 2017 & $\mathrm{X}$ & $\mathrm{X}$ & $\mathrm{X}$ & $\mathrm{X}$ & & $\mathrm{X}$ & $\mathrm{X}$ & $\mathrm{X}$ & $\mathrm{X}$ & $\mathrm{X}$ \\
\hline Anokhin 2011 & & $\mathrm{X}$ & & & $\mathrm{X}$ & & & & $\mathrm{X}$ & \\
\hline Battistella 2017 & $X$ & $\mathrm{X}$ & $X$ & & $\mathrm{X}$ & $X$ & & $X$ & & \\
\hline Belingheri 2017 & $\mathrm{X}$ & & & $\mathrm{X}$ & & & & & $X$ & \\
\hline Chanal 2010 & & $\mathrm{X}$ & & $\mathrm{X}$ & & $\mathrm{X}$ & $\mathrm{X}$ & & $\mathrm{X}$ & \\
\hline Chesbrough 2012 & & $\mathrm{X}$ & & & & & $\mathrm{X}$ & & & \\
\hline Coste 2017 & & $\mathrm{X}$ & & & & $\mathrm{X}$ & & & & \\
\hline Di Pietro 2017 & $\mathrm{X}$ & $\mathrm{X}$ & $\mathrm{X}$ & & & $\mathrm{X}$ & $\mathrm{X}$ & & & \\
\hline Eftekhari 2015 & $\mathrm{X}$ & & & $X$ & $\mathrm{X}$ & & $\mathrm{X}$ & $\mathrm{X}$ & $X$ & $\mathrm{X}$ \\
\hline Ferrary 2011 & & $\mathrm{X}$ & & & $\mathrm{X}$ & & $\mathrm{X}$ & & $\mathrm{X}$ & \\
\hline Ghezzi 2016 & $\mathrm{X}$ & & & $X$ & $\mathrm{X}$ & & & $X$ & $\mathrm{X}$ & $X$ \\
\hline $\begin{array}{c}\text { Gimenez-Fernan- } \\
\text { dez } 2017\end{array}$ & $\mathrm{X}$ & $\mathrm{X}$ & $\mathrm{X}$ & & $\mathrm{X}$ & & $\mathrm{X}$ & $\mathrm{X}$ & $\mathrm{X}$ & $\mathrm{X}$ \\
\hline Gruber 2006 & $X$ & & & $\mathrm{X}$ & $X$ & & $X$ & $X$ & & \\
\hline Hasche 2017 & $X$ & $X$ & $\mathrm{X}$ & & & & $X$ & $\mathrm{X}$ & $X$ & $X$ \\
\hline Homfeldt 2017 & & $X$ & & & & & $X$ & & $X$ & \\
\hline Hsieh 2016 & $\mathrm{X}$ & & & $\mathrm{X}$ & & & & $\mathrm{X}$ & $\mathrm{X}$ & \\
\hline Idelchik 2012 & & $\mathrm{X}$ & & & & & $\mathrm{X}$ & & & \\
\hline Jackson 2015 & & $\mathrm{X}$ & & & $\mathrm{X}$ & & & & $\mathrm{X}$ & \\
\hline Jackson 2017 & $\mathrm{X}$ & $\mathrm{X}$ & $\mathrm{X}$ & $\mathrm{X}$ & & & $\mathrm{X}$ & $X$ & $\mathrm{X}$ & $\mathrm{X}$ \\
\hline Kohler 2016 & & $\mathrm{X}$ & & & & & $\mathrm{X}$ & & & \\
\hline Kupp 2017 & & $\mathrm{X}$ & & & & $\mathrm{X}$ & $\mathrm{X}$ & & & \\
\hline Livieratos 2017 & & $\mathrm{X}$ & & & & & $\mathrm{X}$ & & $X$ & \\
\hline Michelino 2017 & $\mathrm{X}$ & & & & $X$ & & $\mathrm{X}$ & $X$ & $\mathrm{X}$ & $X$ \\
\hline Minshall 2007 & & $\mathrm{X}$ & & & $\mathrm{X}$ & & $\mathrm{X}$ & & $\mathrm{X}$ & \\
\hline Minshall 2010 & $\mathrm{X}$ & $\mathrm{X}$ & $X$ & & & $\mathrm{X}$ & $\mathrm{X}$ & $X$ & $\mathrm{X}$ & \\
\hline Napp 2011 & & $\mathrm{X}$ & & & & & $\mathrm{X}$ & & & \\
\hline Neyens 2010 & $\mathrm{X}$ & & & & & & $\mathrm{X}$ & $\mathrm{X}$ & & \\
\hline Piva 2012 & $\mathrm{X}$ & & & $\mathrm{X}$ & & & & & & \\
\hline Richter 2017 & & $\mathrm{X}$ & & & $\mathrm{X}$ & & & & $\mathrm{X}$ & \\
\hline Spender 2017 & $\mathrm{X}$ & & & $\mathrm{X}$ & $\mathrm{X}$ & $\mathrm{X}$ & $\mathrm{X}$ & $\mathrm{X}$ & $\mathrm{X}$ & $\mathrm{X}$ \\
\hline Usman 2016 & $\mathrm{X}$ & & & $\mathrm{X}$ & $\mathrm{X}$ & & $\mathrm{X}$ & $\mathrm{X}$ & & \\
\hline van Gils 2017 & $\mathrm{X}$ & $\mathrm{X}$ & $\mathrm{X}$ & & $\mathrm{X}$ & & $\mathrm{X}$ & $\mathrm{X}$ & & \\
\hline $\begin{array}{l}\text { Waguespack } \\
2009\end{array}$ & $\mathrm{X}$ & & & & & $\mathrm{X}$ & $\mathrm{X}$ & & & \\
\hline Weiblen 2015 & $\mathrm{X}$ & $\mathrm{X}$ & $\mathrm{X}$ & & & $\mathrm{X}$ & $\mathrm{X}$ & & & \\
\hline TOTAL & 20 & 23 & 9 & 11 & 14 & 10 & 25 & 15 & 19 & 8 \\
\hline
\end{tabular}

Research has shown that collaborations with other actors can positively influence the performance of a start-up. van Gils and Rutjes (2017) examined how a start-up can benefit from being part of an innovation ecosystem. They find that being in an open environment allows start-ups to overcome some initial limits that characterize it.

As mentioned, the most analyzed topic concerns the ties, which deal with the relationships that start-ups have with their stakeholders (suppliers, customers, universities, etc.). Eftekhari and Bogers (2015) found that collaborations with various partners could allow start-ups to exceed their initial limits. The authors suggest that start-ups should work together with customers to get a successful product/service and then increase their survivability. Hasche et al. (2017) considered the importance of trust in OI; for them, successful collaboration is synonymous with mutual trust between the parties involved. However, the trust could fail; in fact, sometimes start-ups perceive a lack of goodwill on the part of the collaborator and sometimes, it is the large companies that do not believe the skills of the start-up. Jackson et al. (2017) studied the barriers that hinder the collaborations between start-ups and large companies. They found that there are two significant barriers: "restrictive mindset" and "conservative decision making". The authors formulated some propositions that can guide collaborations among the subjects. In 
their study, Michelino et al. (2017) placed their attention on the mutual influence of OI collaboration, finding that the propensity to collaborate influences the innovation output. Minshall et al. (2010) focused on the asymmetric information that characterizes the collaborations between large companies and start-ups. Neyens et al. (2010) investigated how the duration of alliances influences the innovation performance of start-ups. In particular, discontinuous alliances with suppliers and customers favour incremental innovation, while alliances with suppliers, competitors and universities promote radical innovation. Spender et al. (2017) identified four key players who can support start-ups: incubators, venture capitalists, large corporations and universities. Furthermore, Usman and Vanhaverbeke (2017) analyzed the collaborations between startups and large companies. In this case, the authors point out that start-ups should be skilled in negotiating with large companies and they must consider different risks to avoid future conflicts.

Also, recommendations for further research have been gathered from the reviewed articles. In this sense, the topics recommended for further research appear to be interlinked. Indeed, many authors highlight the importance of studying how collaborations (ties) are influenced by the entrepreneur's open mindset (Eftekhari and Bogers 2015; Jackson and Richter 2017); equally important is to understand how knowledge flows between the subjects (Spender et al. 2017). Openness to external subjects allows start-ups to reach important goals and solve their initial shortcomings (Piva and Lamastra 2012; van Gils and Rutjes 2017); indeed, it is through certain collaborations that start-ups can acquire the knowledge they do not possess (Gassmann et al. 2010; van Gils and Rutjes 2017). Another important aspect of ties is the credibility of the entrepreneur that is influenced by his previous work experience (Usman and Vanhaverbeke 2017). The strategic choices adopted by the entrepreneur influence his way of managing knowledge and eventually spread it to the outside world (Minshall et al. 2010; Spender et al. 2017; Usman and Vanhaverbeke 2017).

All of these factors influence a company's performance, which is therefore for interest for entrepreneurs, incubators and other actors from the entrepreneurial ecosystem. Collaborations can positively influence the survival of a start-up (Eftekhari and Bogers 2015) and the ability to collect funds from investors allows a start-up to anticipate its revenues and therefore be successful (Ghezzi et al. 2016). For some, it is important to understand how being in an open environment influences the innovative, financial and economic performance (Spender et al. 2017).

\section{References}

Alberti, F. G., \& Pizzurno, E. (2017). Oops, I did it again! Knowledge leaks in open innovation networks with start-ups. European Journal of Innovation Management, 20(1), 50-79.

Anokhin, S., Örtqvist, D., Thorgren, S., \& Wincent, J. (2011). Corporate venturing deal syndication and innovation: the information exchange paradox. Long Range Planning, 44(2), 134-151.

Battistella, C., De Toni, A. F., \& Pessot, E. (2017). Open accelerators for start-ups success: a case study. European Journal of Innovation Management, 20(1), 80-111.

Belingheri, P. \& Leone, M.I., (2017). Walking into the room with IP: exploring start-ups' IP licensing strategy. Management Decision, 55(6), pp.1209-1225.

Blank, (2013). Why the lean start-up changes everything 63rd-72nd ed., 5.

Blank, S. \& Dorf, B., 2012. The startup owner's manual: The step-by-step guide for building a great company.

Bogers, M., (2011). The open innovation paradox: knowledge sharing and protection in R\&amp;D collaborations. European Journal of Innovation Management, 14(1), pp.93-117.

Carree, M. A., \& Thurik, A. R. (2010). The impact of entrepreneurship on economic growth. 
In Z. J. Acs \& D. B. Audretsch (Eds.), Handbook of Entrepreneurship Research: An Interdisciplinary Survey and Introduction (2nd ed., pp. 557-594). New York, Dordrecht, Heidelberg and London: SPRINGER.

Chanal, V., \& Caron-Fasan, M. L. (2010). The difficulties involved in developing business models open to innovation communities: the case of a crowdsourcing platform. Management, 13(4), 318-340

Chesbrough, H., (2003). Open innovation: The new imperative for creating and profiting from technology, Harvard Business School Press, Boston.

Chesbrough, H., Vanhaverbeke, W., \& West, J., (2006). Open innovation: Researching a new paradigm, Oxford University Press on Demand.

Chesbrough, H. (2012). GE's ecomagination challenge: an experiment in open innovation. California management review, 54(3), 140-154.

Coste, J. D., \& Gatzke, S. (2017). A novel approach to innovation platforms: Symbiotic on/off spaces, cross-industry sponsor. New Space, 5(3), 155-162.

Di Pietro, F., Prencipe, A., \& Majchrzak, A. (2018). Crowd equity investors: An underutilized asset for open innovation in startups. California Management Review, 60(2), 43-70.

Eftekhari, N. \& Bogers, M., (2015). Open for Entrepreneurship: How Open Innovation Can Foster New Venture Creation. Creativity and Innovation Management, 24(4), pp.574-584.

Ferrary, M. (2011). Specialized organizations and ambidextrous clusters in the open innovation paradigm. European management journal, 29(3), 181-192.

Gassmann, O. \& Enkel, E., (2004). Towards a theory of open innovation: three core process archetypes.

Gassmann, O., Enkel, E. \& Chesbrough, H., (2010). The future of open innovation. $R \& D$ Management, 40(3), pp.213-221.

Ghezzi, A., Gastaldi, L., Lettieri, E., Martini, A., \& Corso, M. (2016). A role for startups in unleashing the disruptive power of social media. International Journal of Information Management, 36(6), 1152-1159.

Gimenez-Fernandez, E. M., \& Beukel, K. (2017). Open innovation and the comparison between startups and incumbent firms in Spain. UCJC Business and Society Review (formerly known as Universia Business Review), (55).

Gruber, M. \& Henkel, J., (2006). New ventures based on open innovation an empirical analysis of start-up firms in embedded Linux. International Journal of Technology Management, 33(4), p.356.

Hasche, N., Linton, G. \& Öberg, C., (2017). Trust in open innovation - the case of a med-tech start-up. European Journal of Innovation Management, 20(1), pp.31-49.

Hidalgo, A., Gabaly, S., Morales-Alonso, G., \& Urueña, A. (2020). The digital divide in light of sustainable development: An approach through advanced machine learning techniques. Technological Forecasting and Social Change, 150, 119754.

Homfeldt, F., Rese, A., Brenner, H., Baier, D., \& Schäfer, T. F. (2017). Identification and generation of innovative ideas in the procurement of the automotive industry: The case of Audi AG. International Journal of Innovation Management, 21(07), 1750053.

Hsieh, C.-T., Huang, H.-C. \& Lee, W.-L., (2016). Using transaction cost economics to explain open innovation in start-ups. Management Decision, 54(9), pp.2133-2156.

Idelchik, M., \& Kogan, S. (2012). GE's open collaboration model. Research-Technology Management, 55(4), 28-31.

Jackson, P. \& Richter, N., (2017). Situational Logic: an Analysis of Open Innovation Using Corporate Accelerators. International Journal of Innovation Management, 21(07), p.1750062.

Jackson, P., Richter, N., \& Schildhauer, T. (2015). Open Innovation with digital startups using 
Corporate Acelerators-A review of the current state of research. Zeitschrift für Politikberatung (ZPB)/Policy Advice and Political Consulting, 7(4), 152-159.

Janssen, W., Bouwman, H., van Buuren, R., \& Haaker, T. (2014). An organizational competence model for innovation intermediaries. European Journal of Innovation Management, 17(1), 2-24.

Johnsen, T., Miemczyk, J. \& Management, M.H., (2017). A systematic literature review of sustainable purchasing and supply research: Theoretical perspectives and opportunities for IMP-based research. Industrial Marketing Management, (61), pp.130-143.

Kohler, T., (2016). Corporate accelerators: Building bridges between corporations and startups. Business Horizons, 59(3), pp.347-357.

Kupp, M., Marval, M., \& Borchers, P. (2017). Corporate accelerators: fostering innovation while bringing together startups and large firms. Journal of business strategy.

Livieratos, A.D. \& Lepeniotis, P., (2017). Corporate venture capital programs of European electric utilities: Motives, trends, strategies and challenges. Electricity Journal, 30(2), pp.30-40.

Michelino, F., Cammarano, A., Lamberti, E., \& Caputo, M. (2017). Open innovation for startups: A patent-based analysis of bio-pharmaceutical firms at the knowledge domain level. European Journal of Innovation Management, 20(1), 112-134.

Minshall, T. I. M., Seldon, S., \& Probert, D. (2007). Commercializing a disruptive technology based upon University IP through Open Innovation: A case study of Cambridge Display Technology. International Journal of Innovation and Technology Management, 4(03), 225239.

Minshall, T., Mortara, L., Valli, R., \& Probert, D. (2010). Making “asymmetric" partnerships work. Research-Technology Management, 53(3), 53-63.

Morales-Alonso, G., Guerrero, Y. N., Aguilera, J. F., \& Rodríguez-Monroy, C. (2020). Entrepreneurial aspirations: economic development, inequalities and cultural values. European Journal of Innovation Management.

Morales-Alonso, G., Pablo-Lerchundi, I. \& Núñez-Del-Río, M.-C., (2016). Entrepreneurial intention of engineering students and associated influence of contextual factors. Revista de Psicología Social, 31(1), pp.75-108.

Morales-Alonso, G., Vila, G. A., Lemus-Aguilar, I., \& Hidalgo, A. (2019). Data retrieval from online social media networks for defining business angels' profile. Journal of Enterprising Communities: People and Places in the Global Economy.

Napp, J. J., \& Minshall, T. (2011). Corporate venture capital investments for enhancing innovation: Challenges and solutions. Research-Technology Management, 54(2), 27-36.

Neyens, I., Faems, D. \& Sels, L., (2010). The impact of continuous and discontinuous alliance strategies on startup innovation performance. International Journal of Technology Management, 52(3/4), p.392.

Piva, E. \& Lamastra, C.R., (2012). Does free/open source software enable new forms of entrepreneurship? An analysis of the start-ups created to exploit the business opportunities stemming from free/open source software. International Journal of Entrepreneurship and Innovation Management, 16(3/4), p.173.

Richter, N., Jackson, P., \& Schildhauer, T. (2018). Outsourcing creativity: An abductive study of open innovation using corporate accelerators. Creativity and Innovation Management, 27(1), 69-78.

Spender, J. C., Corvello, V., Grimaldi, M., \& Rippa, P. (2017). Startups and open innovation: a review of the literature. European Journal of Innovation Management, 20(1), 4-30.

Usman, M. \& Vanhaverbeke, W., (2017). How start-ups successfully organize and manage open innovation with large companies. European Journal of Innovation Management, 20(1), 
pp.171-186.

van Gils, M.J.G.M. \& Rutjes, F.P.J.T., (2017). Accelerating chemical start-ups in ecosystems: the need for biotopes. European Journal of Innovation Management, 20(1), pp.135-152.

Waguespack, D. M., \& Fleming, L. (2009). Scanning the commons? Evidence on the benefits to startups participating in open standards development. Management Science, 55(2), 210223.

Weiblen, T., \& Chesbrough, H. W. (2015). Engaging with startups to enhance corporate innovation. California Management Review, 57(2), 66-90.

Wennekers, S., \& Thurik, R., (1999). Linking entrepreneurship and economic growth. Small Business Economics, 13(1), pp.27-56. 